\title{
Bryoflora of Gallery Forest in Quirinópolis, Goiás State, Brazil ${ }^{1}$
}

\author{
Herla Ferreira de Aquino $^{2}$, Isa Lucia de Morais Resende ${ }^{2,5}$, Denilson Fernandes Peralta ${ }^{3}$ and \\ Lucas Matheus da Rocha ${ }^{4}$
}

Received: 29.08.2014; accepted: 23.03.2015

\begin{abstract}
Bryoflora of Gallery Forest in Quirinópolis, Goiás State, Brazil). This study provides a survey of the bryophytes in gallery forest in the municipality of Quirinópolis, Goiás State, Brazil. Samples were collected monthly from April 2012 to July 2013. The substrate colonization and frequency of species were analyzed. The material was collected according to the usual procedures and is deposited at HerbJAR of UEG. We found 38 species of bryophytes (25 mosses and 13 liverworts). The richest families were Hypnaceae for mosses and Lejeuneaceae for liverworts, with five and seven species recorded, respectively. Isopterygium tenerum (Sw.) Mitt. was the most frequent species, and has a wide distribution in Brazil. Dicranodontium pulchroalare subsp. brasiliense (Herzog) J.-P.Frahm is a new record for the Cerrado, and Philonotis sphaericarpa (Hedw.) Brid., Lejeunea caulicalyx (Steph.) E. Reiner, and L. quinque-umbonata Spruce are new records for Goiás State.
\end{abstract}

Keywords: Brazilian savanna, bryophytes, liverworts, mosses, wetlands

RESUMO - (Brioflora de Mata de Galeria Inundável em Quirinópolis, Estado de Goiás, Brasil). O presente estudo objetivou realizar um levantamento da brioflora em mata de galeria no município de Quirinópolis, Goiás. As coletas foram realizadas mensalmente de abril de 2012 a julho de 2013. Foram analisadas a colonização do substrato e a frequência das espécies. O material coletado foi herborizado conforme os procedimentos usuais e está depositado no HerbJAR da UEG. As identificações foram feitas por especialistas. Foram encontradas 38 espécies de briófitas (25 musgos e 13 hepáticas). As famílias mais ricas foram Hypnaceae para musgos e Lejeuneaceae para hepáticas, com cinco e sete espécies registradas, respectivamente. Isopterygium tenerum (Sw.) Mitt. foi a espécie mais frequente, o qual apresenta ampla distribuição no Brasil. Dicranodontium pulchroalare subsp. brasiliense (Herzog) J.-P.Frahm é um novo registro para o bioma Cerrado, e Philonotis sphaericarpa (Hedw.) Brid., Lejeunea caulicalyx (Steph.) E. Reiner e L. quinque-umbonata Spruce novos registros para o Estado de Goiás. Palavras-chave: áreas úmidas, briófitas, Cerrado, hepática, musgo

\section{Introduction}

The Cerrado is the second largest Brazilian biome in extension (Silva et al. 2008), formed by different phytophysiognomies (Visnadi 2004). The gallery forests constitute the humid areas in the Cerrado, occupying the banks of streams and small rivers, forming closed corridors above them (Ribeiro \& Walter 2008). These environments are proper to the occurrence of bryophytes, since these plants exhibit dependence on water for reproduction (Weberling \& Schwantes 1986).

One of the first surveys on the bryoflora in the Cerrado has been performed in Distrito Federal (Filgueiras \& Pereira 1993), who reported 126 species of bryophytes. Since then, the number of bryologic inventories has increased in the last years (Glime 2006, Alvarenga et al. 2007). Today, 479 species are listed to

1. Trabalho de Conclusão de Curso da primeira Autora, Universidade Estadual de Goiás, Curso de Ciências Biológicas

2. Universidade Estadual de Goiás, Curso de Ciências Biológicas, , Herbário José Ângelo Rizzo, Unidade de Quirinópolis, Av. Brasil, Quadra 3, Lote 1, Conjunto Hélio Leão, 75860-000 Quirinópolis, GO, Brasil

3. Instituto de Botânica, Av. Miguel Stéfano, 3687, 04301902 São Paulo, SP, Brasil

4. Universidade Federal de Uberlândia, Campus do Pontal, Faculdade de Ciências Integradas do Pontal, Rua 20, 1600, Tupã, 38304-402 Ituiutaba, MG, Brasil

5. Corresponding author: isamorais1@gmail.com 
Cerrado, and 309 of these species to Goiás State (Yano \& Costa 2000, Gradstein et al. 2005, Yano \& Peralta 2007, Yano \& Peralta 2008, Costa 2013).

The bryologic surveys in the Cerrado have focus on floristic surveys (Vital 1983, Egunyomi \& Vital 1984, Vilas Bôas-Bastos \& Bastos 1998, Visnadi \& Vital 2001, Castro et al. 2002, Visnadi 2004). The studies involving the abundance and richness of bryophytes are few, and there are only two studies on gallery forests (Peralta \& Yano 2005, Genevro et al. 2006). For the of Goiás State, the survey in the gallery forest of Vale da Lua, Chapada dos Veadeiros with 33 species of mosses (Faria et al. 2012, Pinheiro et al. 2012), which registered 36 species of liveworts, being six new records for the Center-West and eight new records for Goiás State, and registered 52 new species of moss, being 15 new records for Goiás State, 7 for the Center-West Region, in clumps at Parque Nacional da Chapada dos Veadeiros (Pinheiro 2012).

Thus, in order to contribute to the knowledge on the distribution and richness of the bryoflora, this study aimed to evaluate the diversity and richness of bryophytes in the gallery forest of Quirinópolis, Goiás State.

\section{Material and methods}

The study area is a gallery forest in the city Quirinópolis, located around $50 \mathrm{~km}$ from the county seat $\left(18^{\circ} 33^{\prime} 2.76^{\prime \prime} \mathrm{S}-50^{\circ} 46^{\prime} 7.99^{\prime \prime} \mathrm{W}\right)$ of Quirinópolis, Goiás State. The municipality is part of the Cerrado biome, in the Microregion 18 and Mesoregion South Goiano (IBGE 2010).

The samples were made between April 2012 and July 2013, following the usual methodology proposed by Frahm (2003). The especimens were collected through the polygonation method (Filgueiras et al. 1994), in a way to cover the different environmental gradients present in the phytophysionomy studied.

According to the substrate where the samples were collected, they were classified as corticolous, on the bark of living trees; epixylous, on dead or decaying wood; epiphyllous, on living leaves; rupicolous, on rocks; and terricolous, on the soil or litter (Robbins 1952).

The material collected was herborized according to the usual procedures and included in the collection of José Ângelo Rizzo Herbarium (HERBJAR), of the Universidade Estadual de Goiás (UEG), Unidade de Quirinópolis.

The absolute frequency of the species was determined based on the number of occurrences, where five classes were defined: 1-5: rare, 6-10: infrequent; 11-20: assiduous; 21-30: frequent; and $>$ 31: very frequent (Silva \& Pôrto 2007). The assiduous, frequent and very frequent species were classified into photophilic species (those occurring in sunny locations in open areas of gallery forest), shade species (those that occur in the shaded areas of the gallery forest), and generalists (adapted from Gradstein 1992).

The identification of the samples was based on the work of Yano (1975), Vital (1980), Reese (1993), Gradstein (1994), Sharp et al. (1994), Buck and Goffinet (2000), Crandall-Stotler and Stotler (2000), Buck (2003), Gradstein and Costa (2003), Stotler and Crandall-Stotler (2005), Alvarenga et al. (2007), Pursell (2007); and compared to the samples identified by experts previously.

The classification system adopted was Buck and Goffinet (2000) to Bryophyta and Crandall-Stotler \& Stotler (2000) to Marchantiophyta.

\section{Results and Discussion}

Were studied 139 samples and 38 species of bryophytes were found. Mosses are represented by 14 families, 21 genera and 25 species, and liverworts by six families, 10 genera and 13 species. One morphospecie of Lejeuneaceae was identified in genus for not having the necessary structures for the identification of the specie (table 1).

In the study area, some species considered rare were sampled because they were poorly sampled in the country, being these the Dicranodontium pulchroalare subsp. brasiliense, Orthostichidium quadrangulare mosses, and the Riccardia chamedryfolia, Taxilejeunea isocalycina, Zoopsidella macella e Porella swartziana liverworts.

Dicranodontium pulchroalare subsp. brasiliense, an endemic species to Brazil, is a new occurrence for the Cerrado biome. This moss had only been sampled in the Mata Atlântica, in the States of Ceará, Minas Gerais, and Rio de Janeiro (Costa \& Peralta 2014).

Philonotis sphaerocarpa, Lejeunea caulicalyx and L. quinque-umbonata are new records for Goiás State. Taxilejeunea isocalycina constituted a new record for the Goiás State in a survey in two paths of Quirinópolis, Goiás State, being collected on soil, in light and humid locations (Bernardes et al. 2012). All other species found are widely distributed in Brazil and in other neotropical areas, occurring in at least four Brazilian States (Costa \& Peralta 2014). 
Table 1. Species found in a swamp gallery forest of Quirinópolis, Goiás State, Brazil, listed in alphabetical order by family. *: New record for the Goiás State. **: New record for the Center-West region. Substrate: C: corticolous; EX: epixylous; T: terricolous; R: rupicolous. Freq.: Number of samples.

\begin{tabular}{|c|c|c|c|c|c|c|c|}
\hline \multirow{2}{*}{ Category/Family } & \multirow{2}{*}{ Species } & \multicolumn{4}{|c|}{ Substrate type } & \multirow{2}{*}{ Freq. } & \multirow{2}{*}{ Voucher } \\
\hline & & $\mathrm{C}$ & EX & $\mathrm{T}$ & $\mathrm{R}$ & & \\
\hline \multicolumn{8}{|l|}{ Bryophyta } \\
\hline Bartramiaceae & Philonotis sphaerocarpa (Hedw.) Brid.* & & & $\mathrm{X}$ & & 2 & Aquino 29 \\
\hline \multirow[t]{2}{*}{ Dicranaceae } & $\begin{array}{l}\text { Dicranodontium pulchroalare subsp. brasiliense } \\
\text { (Herzog) J.-P. Frahm.** }\end{array}$ & & & $\mathrm{X}$ & & 1 & Resende 1715 \\
\hline & Ochrobryum gardneri (Müll. Hal.) Mitt. & $\mathrm{X}$ & & & & 3 & Aquino 65 \\
\hline Entodontaceae & Erythrodontium longisetum (Hook.) Paris & $\mathrm{X}$ & & & & 3 & Resende 1694 \\
\hline Fissidentaceae & Fissidens hornschuchii Mont. & $\mathrm{X}$ & & & & 1 & Aquino 6 \\
\hline \multirow[t]{5}{*}{ Hypnaceae } & Chryso-hypnum diminutivum (Hampe) W.R. Buck & $\mathrm{X}$ & $\mathrm{X}$ & $\mathrm{X}$ & $\mathrm{X}$ & 16 & Aquino 52 \\
\hline & Chryso-hypnum elegantulum (Hook.) Hampe & $\mathrm{X}$ & & & & 1 & Aquino 38 \\
\hline & Isopterygium tenerifolium Mitt. & $\mathrm{X}$ & $\mathrm{X}$ & $\mathrm{X}$ & & 6 & Aquino 22 \\
\hline & Isopterygium tenerum (Sw.) Mitt. & $\mathrm{X}$ & $\mathrm{X}$ & $\mathrm{X}$ & & 30 & Aquino 88 \\
\hline & Vesicularia vesicularis (Schwäegr.) Broth. & & & $\mathrm{X}$ & & 1 & Aquino 72 \\
\hline \multirow[t]{2}{*}{ Meteoriaceae } & Floribundaria flaccida (Mitt.) Broth. & $\mathrm{X}$ & & & & 1 & Resende 1704 \\
\hline & Meteorium nigrescens (Hedw.) Dozy \& Molk. & $\mathrm{X}$ & $\mathrm{X}$ & & & 13 & Resende 1700 \\
\hline \multirow[t]{2}{*}{ Neckeraceae } & Neckeropsis disticha (Hedw.) Kindb. & $\mathrm{X}$ & & & & 1 & Resende 1646 \\
\hline & Neckeropsis undulata (Hedw.) Reichardt & $\mathrm{X}$ & $\mathrm{X}$ & & & 16 & Resende 1697 \\
\hline \multirow[t]{2}{*}{ Pilotrichaceae } & Callicostella pallida (Hornsch.) Ângstr. & $\mathrm{X}$ & & & & 1 & Aquino 4 \\
\hline & Cyclodictyon albicans (Hedw.) O. Kuntze & & $\mathrm{X}$ & & & 1 & Aquino 85 \\
\hline Pottiaceae & Pseudosymblepharis schimperiana (Paris) H.A.Crum & $\mathrm{X}$ & & & & 2 & Resende 1727 \\
\hline \multirow[t]{3}{*}{ Pterobryaceae } & Henicodium geniculatum (Mitt.) W.R. Buck & $\mathrm{X}$ & & & & 1 & Aquino 75 \\
\hline & Jaegerina scariosa (Lorentz) Arzeni & $\mathrm{X}$ & & & & 6 & Aquino 71 \\
\hline & Orthostichidium quadrangulare (Schwägr.) B.H. Allen & $\mathrm{X}$ & & & & 1 & Resende 1649 \\
\hline Racopilaceae & Racopilum tomentosum (Hedw.) Brid. & $\mathrm{X}$ & & & & 2 & Resende 1657 \\
\hline \multirow[t]{2}{*}{ Sematophyllaceae } & Sematophyllum subpinnatum (Brid.) E. Britton & $\mathrm{X}$ & & & & 1 & Aquino 82 \\
\hline & Sematophyllum subsimplex (Hedw.) Mitt. & & $\mathrm{X}$ & & & 1 & Aquino 96 \\
\hline Stereophyllaceae & Entodontopsis leucostega (Brid.) W.R. Buck \& Ireland & $\mathrm{X}$ & & & & 2 & Aquino 64 \\
\hline Thuidiaceae & Pelekium schistocalyx (Müll. Hal.) Touw & $\mathrm{X}$ & & $\mathrm{X}$ & & 2 & Aquino 79 \\
\hline \multicolumn{8}{|l|}{ Marchantiophyta } \\
\hline Aneuraceae & Riccardia chamedryfolia (With.) Grolle & & & $\mathrm{X}$ & & 1 & Resende 1714 \\
\hline Frullaniaceae & Frullania ericoides (Nees ex Mart.) Mont. & $\mathrm{X}$ & & & & 2 & Aquino 95 \\
\hline \multirow[t]{7}{*}{ Lejeuneaceae } & Cheilolejeunea rigidula (Mont.) R.M. Schust & $\mathrm{X}$ & & & & 1 & Aquino 24 \\
\hline & Lejeunea caulicalyx (Steph.) E. Reiner \& Goda* & & $\mathrm{X}$ & & & 1 & Aquino 91 \\
\hline & Lejeunea laetevirens Nees \& Mont. & $\mathrm{X}$ & $\mathrm{X}$ & & & 2 & Aquino 92 \\
\hline & Lejeunea quinque-umbonata Spruce & $\mathrm{X}$ & & & & 3 & Aquino 5 \\
\hline & Lejeunea sp. & $\mathrm{X}$ & & & & 1 & Resende 1732 \\
\hline & Mastigolejeunea auriculata (Wilson \& Hook) Schiffn. & $\mathrm{X}$ & $\mathrm{X}$ & & & 6 & Aquino 26 \\
\hline & Taxilejeunea isocalycina (Nees) Steph. & $\mathrm{X}$ & & & & 1 & Resende 1731 \\
\hline \multirow[t]{2}{*}{ Lepidoziaceae } & Telaranea nematodes (Austin) M. Howe & & & $\mathrm{X}$ & & 1 & Resende 1713 \\
\hline & Zoopsidella macella (Spruce) R.M. Schust. & $\mathrm{X}$ & & & & 1 & Aquino 2 \\
\hline Pallaviciniaceae & Symphyogyna brasiliensis Nees & & & $\mathrm{X}$ & & 1 & Resende 1716 \\
\hline Porellaceae & Porella swartziana (F.Web.) Trevis. & $\mathrm{X}$ & & & & 3 & Resende 1703 \\
\hline \multicolumn{2}{|c|}{ Total species found in each substrate } & 31 & 10 & 10 & 1 & & \\
\hline
\end{tabular}


According to the List of Species of Brazilian Flora, regarding distribution in Brazilian phytogeographic areas, $83 \%$ of the species from the gallery forest studied occur in three or more phytogeographic areas. Dicranodontium pulchroalare subsp. brasiliense and Orthostichidium quadrangulare were registered as occurring only in the Mata Atlântica, and Taxilejeunea isocalycina as occurring in the Mata Atlântica and the Amazônia. Therefore, from the total of 35 species found (not included the six species of Lejeunea identified to the genus level), 34 species occur in the Mata Atlântica biome and the Cerrado (97\%); 28 species occur in Amazônia (80\%); 23 species occur in the Pantanal (66\%); twelve species occur in the Caatinga (34\%); and six species have occurred in the Pampas (17\%).

Among the mosses, the family that had the highest species richness was Hypnaceae, with five species, followed by Pterobryaceae with three species, Dicranaceae, Meteoriaceae, Neckeraceae, Pilotrichaceae, and Sematophyllaceae, with two species each. All other families had only one species. Except for Dicranaceae, those were the most representative families in study in swamp forest, in the municipality of Zacarias, northwest of São Paulo State (Peralta \& Yano 2005). Sematophyllaceae and Hypnaceae were also the most representative in the gallery forest at Parque Municipal Mário Viana, in Nova Xavantina, Mato Grosso State (Genevro et al. 2006).

In the liverworts, the family of most richness was Lejeuneaceae, with 11 species and Lepidoziaceae with two species. Lejeuneaceae is among the families with greater diversity occurring in Brazil (Costa \& LuiziPonzo 2010), being the most representative in the study of swamp forest in the municipality of Zacarias, northwest of São Paulo State (Peralta \& Yano 2005), and in the gallery forest at Parque Municipal Mario Viana, Nova Xavantina, Mato Grosso State (Genevro et al. 2006).

The floristic similarity between the gallery forest of the present study and the areas studied by Peralta and Yano (2005) and Genevro et al. (2006), measured by the index of qualitative similarity Sørensen (Mueller-Dombois \& Ellenberg 1974), was of 24\% and 26\%, respectively. According to Kent and Coker (1992), values higher than or equal to $50 \%$ indicate high similarity. Thus, according to this concept, the similarity between the analyzed areas can be considered as low. They were common to the three wetlands among Erythrodontium longisetum, Chrysohypnum diminutivum, Isopterygium tenerifolium,
I. tenerum, Callicostella pallida, Henicodium geniculatum, Jaegerina scariosa and Entodontopsis leucostega mosses; and among Frullania ericoides, Cheilolejeunea rigidula and Mastigolejeunea auriculata liverworts.

In studies conducted in the gallery forest of the Reserva Ecológica of IBGE, RECOR, Distrito Federal, Ochrobryum gardneri, Chryso-hypnum diminutivum, C. elegantulum, Isopterygium tenerum, Racopilum tomentosum, Meteorium nigrescens, Jaegerina scariosa, Sematophyllum subpinnatum, and $S$. subsimplex were common among 41 species of mosses sampled by Câmara (2008a) and Câmara (2008b); Riccardia chamedryfolia, Frullania ericoides, Telaranea nematodes, and Symphyogyna brasiliensis were common among the 18 species of liverworts recorded by Câmara and Costa (2006). The floristic similarity between these areas and the present study was also low (21\%).

The floristic similarity between areas of clumps of forest at the Parque Nacional da Chapada dos Veadeiros, Goiás State and the present study was also low (16\%). Among these areas, the Ochrobryum gardneri, Chryso-hypnum diminutivum, Chrysohypnum elegantulum, Isopterygium tenerifolium, I. tenerum, Neckeropsis undulata, Jaegerina scariosa, Racopilum tomentosum, and Sematophyllum subsimplex mosses (Pinheiro 2012); and the Riccardia chamedryfolia, Frullania ericoides, and Telaranea nematodes liverworts (Pinheiro et al. 2012) were common.

Bryophytes were found on four substrate types: moist-soil (terricolous), living bark (corticolous), decaying wood (epixylous), and rock (rupicolous). Most species was exclusive to only one type of substrate, being the corticolous most often colonized (table 1). From the species that occurred on only one type of substrate, 23 were found on living barks, six on soil, and only three (Cyclodictyon albicans, Sematophyllum subsimplex and Lejeunea caulicalyx) on decaying wood. The corticolous substrate was also the most prevalent habit in swamp woods, in the municipality of Zacarias, northwest of São Paulo State (Peralta \& Yano 2005) and in the gallery forest at Parque Municipal Mário Viana, in Nova Xavantina, Mato Grosso State (Genevro et al. 2006).

Only eight species occurred on two or more substrates. Chryso-hypnum diminutivum was found on all substrates and the only one on rupicolous substrate. According to Yano and Peralta (2007) this species can be found on sandy substrate, as well as on walls of caves, usually occurring on rocks of humid locations. 
According to the frequency, most species was considered rare due to its low number of occurrences (1 to 3). Only three species, Isopterygium tenerifolium, Jaegerina scariosa, and Mastigolejeunea auriculata, were considered infrequent, with six occurrences each. Meteorium nigrescens, Chryso-Hypnum diminutivum, and Neckeropsis undulata were considered assiduous, with 13,16 , and 16 occurrences, respectively.

Isopterygium tenerum moss was the most abundant among the analyzed samples, with 30 occurrences, being considered frequent in the region. This moss occurs throughout the Americas and has wide distribution in Brazil (Yano 2011). It was sampled on living bark, decaying wood and on the soil, along the entire length of the gallery forest studied. It is a species that commonly grows on dry locations and can also be found in waterlogged locations (Hirai et al. 1998), as the physiognomy studied.

Among the liverworts, the most abundant was Mastigolejeunea auriculata, with six occurrences. This species was sampled on living bark and on decaying wood, and had been found on soil and rock. It may be associated with Jaegerina scariosa and Henicodium geniculatum (Yano \& Peralta 2008).

Among the assiduous species, Meteorium nigrescens is photophilic, occurring on living bark, decaying wood, and sometimes on rocks and river banks (Gradstein1992, Yano \& Peralta 2007). Neckeropsis undulata occurs on living bark and decaying wood, in humid forest environments, as well as being sampled on rock and moist-soil (Yano \& Peralta 2007), being considered a generalist species (Gradstein1992). Chryso-hypnum diminutivum was found on all sampled substrates, and is considered a generalist species. Isopterygium tenerum, also generalist, was found on living bark, decaying wood, and soil.

Among the species sampled in the gallery forest, only Zoopsidella macella does not occur in the Mata Atlântica. The low floristic similarity with other wetlands studied in the Center-West Region indicates that the bryophytes of the gallery forest of the present study differ from species surveyed in these environments. The results presented here aim to legitimize the need to intensify the inventories of the flora of bryophytes, including in gallery forests, which are largely responsible for the richness of the microbiota in the Cerrado.

Accordingly, further studies should be conducted to determine the bryoflora in the Goiás State, since three species of bryophytes are reported in this study as new records for the State and for the Cerrado biome.

\section{Literature cited}

Alvarenga, L.D.P., Lisboa, R.C.L. \& Tavares, A.C.C. 2007. Novas referências de hepáticas (Marchantiophyta) da Floresta Nacional de Caxiuanã para o Estado do Pará, Brasil. Acta Botanica Brasilica 21: 649-656.

Bernardes, R.C., Cabral, M.S.D. \& Resende, I.L.M. 2012. Musgos e hepáticas de veredas de Quirinópolis, GO. Anais do X Seminário de Iniciação Científica, VII Jornada de Pesquisa. Pró-Reitoria de Pesquisa e PósGraduação - UEG, Anápolis (GO).

Buck, W.R. 2003. Guide to the plants of Central French Guiana: Mosses. Memoirs of The New York Botanical Garden 76: 1-167.

Buck, W.R. \& Goffinet, B. 2000. Morphology and classification of mosses. In: Shaw, A.J. \& Goffinet, B. (eds.). Bryophyte Biology, Cambrydge University Press, England, pp. 71-123.

Câmara, P.S. 2008a. Musgos acrocárpicos das Matas de Galeria da Reserva Ecológica do IBGE, RECOR, Distrito Federal, Brasil. Acta Botanica Brasilica 22: 1027-1035.

Câmara, P.S. 2008b. Musgos pleurocárpicos das matas de galeria da Reserva Ecológica do IBGE, RECOR, Distrito Federal, Brasil. Acta Botanica Brasilica 22: 573-581.

Câmara, P.S. \& Costa, D.P. 2006. Hepáticas e antóceros das matas de galeria da Reserva Ecológica do IBGE, RECOR, Distrito Federal, Brasil. Hoehnea 33: 41-49.

Castro, N.M.C.F., Pôrto, K.C., Yano, O. \& Castro, A.A.J.F. 2002. Levantamento florístico de Bryopsida de cerrado e mata ripícola do Parque Nacional de Sete Cidades, Piauí, Brasil. Acta Botanica Brasilica 16: 61-76.

Costa, D.P. 2013. Briófitas. In: Lista de Espécies da Flora do Brasil. Jardim Botânico do Rio de Janeiro. Available in http://floradobrasil.jbrj.gov.br (access in 15-I-2014).

Costa, D.P. \& Luizi-Ponzo, A.P. 2010. As briófitas do Brasil. In: Forzza, R.C. et al. (orgs.). Catálogo de Plantas e Fungos do Brasil, Andrea Jakobsson Estúdio, Instituto de Pesquisas Jardim Botânico do Rio de Janeiro, Rio de Janeiro, v. 1, pp. 64-65.

Costa, D.P. \& Peralta, D.F. 2014. Philonotis Dicranodontium, Chryso-hypnum, Isopterygium, Vesicularia, Ochrobryum, Floribundaria, Neckeropsis, Henicodium, Hildebrandtiella, Jaegerina, Racopilum, Entodontopsis. In: Lista de Espécies da Flora do Brasil. Jardim Botânico do Rio de Janeiro. Available in http://floradobrasil.jbrj.gov.br (access in 13-I-2014).

Crandall-Stotler, B. \& Stotler, R. 2000. Morphology and classification of the Marchantiophyta. In: Shaw, A.J. \& Goffinet, B. (eds.). Bryophyte Biology, Cambrydge University Press, England, pp. 21-70.

Egunyomi, A.V. \& Vital, D.M. 1984. Comparative studies on the Bryofloras of the Nigerian Savanna and the Brazilian Cerrado I. Revista Brasileira de Botânica 7: 129-136. 
Faria, A.L.A., Dantas, T.S. \& Câmara, P.S. 2012. Musgos do Vale da Lua, Chapada dos Veadeiros, Goiás, Brasil. Heringeriana 6: 9-20.

Filgueiras, T.S. \& Pereira, B.A.S. 1993. Flora do Distrito Federal. In: Pinto, M.N. (org.). Cerrado: Caracterização, Ocupação e Perspectivas. 2 ed. Editora UnB, Brasília.

Filgueiras, T.S., Nogueira, P.E., Brochado, A.L. \& Guala II, G.F. 1994. Caminhamento: um método expedito para levantamentos florísticos qualitativos. Caderno de Geociências 12: 39-43.

Frahm, J.-P. 2003. Manual of tropical bryology. Tropical Bryology 23: 1-195.

Genevro, J.A., Athayde Filho, F.P. \& Peralta, D.F. 2006. Briófitas de mata de galeria no Parque Municipal Mário Viana, Nova Xavantina, Mato Grosso, Brasil. Boletim do Instituto de Botânica (São Paulo) 18: 149-157.

Glime, J.M. 2006. Physiological Ecology. Bryophyte Ecology. Michigan Technological University, International Association of Bryologists, v. 1.

Gradstein, S.R. 1992. Threatened Bryophytes of the Neotropical Rain Forest: a Status Report. Tropical Bryology 6: 83-93.

Gradstein, S.R. 1994. Lejeuneaceae; Ptychantheae, Brachiolejeuneae. Flora Neotropica 62: 1-216.

Gradstein, S.R. \& Costa, D.P. 2003. The Hepaticae and Anthocerotae of Brazil. Memoirs of The New York Botanical Garden 87: 1-318.

Gradstein, S., Schäfer-Verwimp, A. \& Costa, D.P. 2005. The liverworts (Marchantiophyta) of the state of Goiás, Brazil. Revista de Biologia Neotropical 2: 75-108.

Hirai, R.Y., Yano, O. \& Ribas, M.E.G. 1998. Musgos da mata residual do Centro Politécnico (Capão da Educação Física), Curitiba, Paraná, Brasil. Boletim do Instituto de Botânica 11: 81-118.

IBGE. 2010. Instituto Brasileiro de Geografia e Estatística. available in www.ibge.gov.br (access in 21-IV-13).

Kent, M. \& Coker, P. 1992. Vegetation Description and Analysis. Belhaven Press, London.

Mueller-Dombois, D. \& Ellenberg, H. 1974. Aims and methods of vegetation ecology. Willey \& Sons, New York.

Peralta, D.F. \& Yano, O. 2005. Briófitas de mata paludosa, município de Zacarias, Noroeste do Estado de São Paulo, Brasil. Acta Botanica Brasilica 19: 963-977.

Pinheiro, E.M.L. 2012. Levantamento Florístico de Bryophyta de Capões de Mata no Parque Nacional da Chapada dos Veadeiros, Goiás, Brasil. Dissertação de Mestrado, Universidade de Brasília, Brasília.

Pinheiro, E.M.L., Faria, A.L.A. and Câmara, P.E.A.S. 2012. Riqueza de espécies e diversidade de Marchantiophyta (hepáticas) de capões de mata, no Parque Nacional da Chapada dos Veadeiros, Goiás, Brasil. Revista de Biologia Neotropical 9(1): 19-27.

Pursell, R.A. 2007. Fissidentaceae. Flora Neotropica 101: 1-278.

Reese, W.D. 1993. Calymperaceae. Flora Neotropica 58: 1-102.
Ribeiro, J.F. \& Walter, B.M.T. 2008. As principais fitofisionomias do Bioma Cerrado. In: Sano, S.M., Almeida, S.P. \& Ribeiro, J.F. (eds.). Cerrado: Ecologia e Flora, Embrapa Informação Tecnológica, Brasília pp. 151-212.

Robbins, R.G. 1952. Bryophyta Ecology of a dune area in New Zealand. Vegetation. Acta Geobotanica 4: 1-31.

Sharp, A.J., Crum, H. \& Eckel, P.M. 1994. The moss flora of Mexico. Memoirs of The New York Botanical Garden 69(1-2): 1-1113.

Silva, F.A.M., Assad, E.D. \& Evangelista, B.A. 2008. Caracterização Climática do Bioma cerrado. In: Sano, S.M., Almeida, S.P. \& Ribeiro, J.F. (eds.). Cerrado: Ecologia e Flora. Embrapa, Brasília v. 1, pp. 69-88.

Silva, M.P.P. \& Pôrto, K.C. 2007. Composição e riqueza de briófitas epíxilas em fragmentos florestais da Estação Ecológica de Murici, Alagoas. Revista Brasileira de Biociências 5(2): 243-245.

Stotler, R.E. \& Crandall-Stotler, B. 2005. A revised classification of the Anthocerotophyta and a checklist of the horworts of North America, North of Mexico. The Bryologist 108: 16-26.

Vilas Bôas-Bastos, S.B., \& BASTOS, C.J.P. 1998. Briófitas de uma área de Cerrado no município de Alagoinhas, Bahia, Brasil. Tropical Bryology 15: 101-110.

Visnadi, S.R. 2004. Distribuição da brioflora em diferentes fisionomias de cerrado da Reserva Biológica e Estação Experimental de Mogi-Guaçu, SP, Brasil. Acta Botanica Brasilica 18(4): 965-973.

Visnadi, S.R. \& Vital, D.M. 2001. Lista das briófitas de uma área de Cerrado da Reserva Biológica e Estação Experimental de Mogi-Guaçu, SP, Brasil. Vegetália 35: $1-15$.

Vital, D. 1983. Two new species of Jonesiobryum (Musci) from the Brazilian Cerrado Regions. Journal of Bryology 12: 383-391.

Vital, D.M. 1980. Erpodiaceae (Musci) do Brasil. Dissertação de Mestrado, Universidade Estadual de Campinas, Campinas.

Weberling, F. \& Schwantes, H.O. 1986. Taxionomia Vegetal. EPU, São Paulo.

Yano, O. 1975. Leucobryaceae (Musci) do Estado de São Paulo. Dissertação de Mestrado, Escola Paulista de Medicina São Paulo.

Yano, O. 2011. Catálogo de musgos brasileiros: literatura original, basiônimo, localidade-tipo e distribuição geográfica. Instituto de Botânica, São Paulo.

Yano, O. \& Costa, D.P. 2000. Flora dos Estados de Goiás e Tocantins. In: IFP Campos (coord.). Criptógamos, Briófitas. Coleção Rizzo pp. 1-33.

Yano, O. \& Peralta, D.F. 2007. (Série Criptógamos) Musgos (Bryophyta). Flora dos Estados Goiás e Tocantins 6: 1-333.

Yano, O. \& Peralta, D.F. 2008. Criptógamos: Antóceros (Anthocerotophyta) e hepáticas (Marchantiophyta). Flora dos Estados Goiás e Tocantins. 7: 1-277. 